\title{
Fermentation parameters, quality and losses in sugarcane silages treated with chemical additives and a bacterial inoculant
}

\section{André de Faria Pedroso ${ }^{1}$, Armando de Andrade Rodrigues ${ }^{1}$, Waldomiro Barioni Júnior ${ }^{1}$, Gilberto Batista de Souza ${ }^{1}$}

\footnotetext{
${ }^{1}$ Embrapa Pecuária Sudeste, São Carlos, SP, Brazil, 13560-970.
}

\begin{abstract}
The objective of this trial was to evaluate chemical additives and a bacterial inoculant on the inhibition of alcoholic fermentation and reduction of losses in sugarcane silages. Treatments were (doses on a fresh forage basis): without additive (control); urea $(10 \mathrm{~g} / \mathrm{kg})$; urea $(5 \mathrm{~g} / \mathrm{kg})+$ sodium benzoate $(0.5 \mathrm{~g} / \mathrm{kg})$; sodium benzoate $(1 \mathrm{~g} / \mathrm{kg})$; urea + ammonium sulfate in a 9:1 relation $(10 \mathrm{~g} / \mathrm{kg})$; Lactobacillus buchneri $\left(5 \times 10^{4} \mathrm{cfu} / \mathrm{g}\right)$. Silages were produced in $10.16-\times 30-\mathrm{cm}$ PVC tubes, provided with tight lids adapted with Bunsen valves for gas losses quantification. Minisilos were opened 139 days after ensiling. Ethanol content $(227 \mathrm{~g} / \mathrm{kg}$ dry matter - DM) and total DM loss $(30 \%)$ were high in the control silage. All additives, except benzoate, decreased ethanol concentration in silages. Inoculation with $L$. buchneri increased acetic acid content in the silage, resulting in a $41 \%$ reduction in ethanol content and the lowest gas loss among treatments $(15.2 \%)$. There was synergistic effect between additives for the combined use of urea and benzoate. Silage treated with urea + ammonium sulfate has higher content of total digestible nutrients than the silage treated with urea exclusively.
\end{abstract}

Key Words: ammonium sulfate, ethanol, L. buchneri, sodium benzoate, urea, volatile fatty acids

\section{Introduction}

Sugarcane is usually fed fresh to cattle during winter in Brazil. Recently, the pursuit for better feed and field management has led to an increase in its use as silage, although some hurdles must still be overcome. While the forage's high sugar content and low buffering capacity favor lactic acid production and fast $\mathrm{pH}$ drop, its normally high yeast population leads to intense alcoholic fermentation and excessive dry matter loss (DML) during ensilage (Pedroso et al., 2005).

Several anti fungi products have been tested to control yeasts in sugarcane silages. Some have shown poor efficiency and even deleterious effects, like inoculants containing homolactic bacteria (Freitas et al., 2006; Pedroso et al., 2008) while others, although efficient in controlling alcoholic fermentation, may be hazardous to the environment and farm personnel, like $\mathrm{NaOH}$. Sodium benzoate, urea and inoculants containing Lactobacillus buchneri are some of the most studied additives, but the normal variability of results among experiments indicates that further investigations are necessary to broaden database, allowing more accurate predictions (Schmidt, 2008).

Adding urea to sugarcane has long been known as an effective way to correct protein content in the forage (Alvarez \& Preston, 1976). Urea is frequently mixed with ammonium sulfate (9:1) to achieve adequate nitrogen/sulfur

Received July 13, 2010 and accepted June 1, 2011.

Corresponding author: andref@cppse.embrapa.br balance in sugarcane-based diets (Ferreiro et al., 1977). That way, if urea were proved efficient in controlling alcoholic fermentation during the ensilage of sugarcane, a secondary benefit would be the improvement of crude protein (CP) content in the silage, facilitating feed management. Feed management could be further facilitated if application of urea + ammonium sulfate had the same or better effects than urea applied solely.

Few experiments have been carried out to evaluate the combination of additives on sugarcane ensilage (Pedroso et al., 2007; Siqueira et al., 2010). The eventual occurrence of a synergistic effect creates the possibility of using additives in lower doses, possibly reducing the cost of application.

The objective of this experiment was to test additives on the control of alcoholic fermentation and losses in sugarcane silages, evaluating the possibility of occurrence of synergistic effect in the combined use of urea and sodium benzoate, reassessing the effects of urea and benzoate applied exclusively; the feasibility of applying a pre-mixture of ammonium sulfate and urea and the effects of inoculation with L. buchneri.

\section{Material and Methods}

Silages were produced with sugarcane (IAC86-2480), approximately 12 months old, mechanically harvested with 
Mentamit ${ }^{\circledR}$ adjusted for cut length between 5 and $10 \mathrm{~mm}$. Approximately 1,800 $\mathrm{g}$ of the chopped forage were packed into 10.16 x 30-cm PVC tubes (minisilos), provided with tight lids adapted with Bunsen valves for gaseous losses quantification. Forage density in the minisilos averaged $724 \mathrm{~kg} / \mathrm{m}^{3}$.

Treatments differed according to the type of additive applied to the chopped sugarcane before ensiling (doses in a fresh forage basis - FF): without additive (control); urea $(10 \mathrm{~g} / \mathrm{kg})$ - UR; urea $(5 \mathrm{~g} / \mathrm{kg})+$ sodium benzoate $(0.5 \mathrm{~g} / \mathrm{kg})$ - UR + SB; sodium benzoate $(1 \mathrm{~g} / \mathrm{kg})$ - SB; urea + ammonium sulfate in a 9:1 ratio $(10 \mathrm{~g} / \mathrm{kg})$ - UR + AS; Lactobacillus buchneri $\left(5 \times 10^{4} \mathrm{cfu} / \mathrm{g}\right)$ - BUCH. Urea and urea + AS were added to the forage without dilution while sodium benzoate and L. buchneri were applied in aqueous solutions, using manual sprayers. The solution of sodium benzoate was applied at the rate of $4.5 \mathrm{~L} / \mathrm{t} \mathrm{FF}$. The inoculant containing L. buchneri (strain NCIMB 40788, Lalsil Cana ${ }^{\circledR}$, Lallemand S.A., Blagnac, Fr.) was applied according to label (2 g/t) using $1.5 \mathrm{~L}$ of solution/t FF.

Minisilos were weighed and sampled on day 0 and 139 days after ensiling. Dry matter loss was calculated by DM weight loss in the silage. Samples were dried in a forced ventilation oven $\left(65^{\circ} \mathrm{C}, 48 \mathrm{~h}\right)$ and ground in a Wiley mill through a 1-mm screen and analyzed for acid detergent fiber (ADF); neutral detergent fiber (NDF) and lignin, according to Van Soest \& Robertson (1985); DM, ash, crude protein (CP), ether extract and N-ADF, according to AOAC (1990). Content of total digestible nutrients (TDN) in silages was calculated according to Weiss et al. (1992).

Samples for ethanol, $\mathrm{pH}$, volatile fatty acids (VFA) and lactic acid determinations were frozen $\left(-10^{\circ} \mathrm{C}\right)$ until processing for analysis. On the day of processing, samples were thawed and extracts were produced by means of a hydraulic press $\left(2 \mathrm{kgf} / \mathrm{cm}^{3}\right)$. Approximately $300 \mathrm{~g}$ of silage from each sample were used to produce $50 \mathrm{~mL}$ of juice in which $\mathrm{pH}$ was determined with a digital potentiometer. Extracts were centrifuged at 3,000 rpm for $15 \mathrm{~min}$ and $5 \mathrm{~mL}$ of supernatants transferred to $10 \mathrm{~mL}$ test tubes containing $1 \mathrm{~mL}$ of formic acid P.A. From these extracts, $1 \mathrm{~mL}$ was filtered through a Millex filter $(0.45 \mu \mathrm{m})$ and stored $\left(-10{ }^{\circ} \mathrm{C}\right)$ until analysis. Ethanol and VFA were analyzed by gas chromatography according to SigmaAldrich, Co. (1998) and lactic acid using high performance liquid chromatography (HPLC) according to Wilson (1971).

Data were analyzed as a completely randomized design, with six treatments and four replicates, and subjected to ANOVA by the GLM procedure of SAS (SAS, 2003). Differences between means were tested using $t$ test. Significant differences were declared if $\mathrm{P}<0.05$.

\section{Results and Discussion}

The control silage presented concentrations of lactic, acetic, propionic and butyric acids and $\mathrm{pH}$ (Table 1) indicative of adequate fermentation and conservation in traditional silages (Kung \& Shaver, 2001). Nonetheless, ethanol content was extremely high $(227 \mathrm{~g} / \mathrm{kg} \mathrm{DM})$ in the untreated silage (Figure 1), indicating undesirable and intense yeast development.

Silages with intense alcoholic fermentation tend to show inadequate final pH (Driehuis \& Wikselaar, 2000) but the low buffering capacity of sugarcane allows rapid drop in $\mathrm{pH}$ even with relatively small amounts of acids in the silage (Alli et al., 1983) and, despite high levels of ethanol, these silages normally present final $\mathrm{pH}$ around 3.5 (Pedroso et al., 2005).

Yeasts are not inhibited by $\mathrm{pH}$ levels normally found in silages (McDonald et al., 1991) and lactic acid has weak direct fungicidal action (Moon, 1983). Consequently, the low pH and the lactic acid content in the control silage were unable to restrict yeast development, resulting in high gaseous and total DM losses in the silage ( $19.3 \%$ and $29.8 \%$, respectively; Figure 1). High DM loss was expected for the control silage considering that fermentation of sugars by yeasts results in proximately $49 \%$ loss of substratum as $\mathrm{CO}_{2}$ and $\mathrm{H}_{2} \mathrm{O}$ (McDonald et al., 1991). Accordingly, fermentation in the control silage resulted in a $26 \%$ reduction in DM content, relative to the fresh forage (Table 1).

Uncontrolled yeast fermentation during the ensilage of sugarcane may consume up to $70 \%$ of sugars originally present in the forage, causing other components to become more concentrated in DM and a substantial reduction in silage nutritional value (Pedroso et al., 2005). Accordingly, $\mathrm{NDF}, \mathrm{ADF}, \mathrm{CP}$, ash, $\mathrm{Ca}$ and $\mathrm{P}$ concentrations were higher and TDN was $22 \%$ lower in the control silage compared with the fresh sugarcane (Table 1). All these aspects are typical of sugarcane silages produced without additives and have been well documented (Pedroso et al., 2005; Siqueira et al., 2010).

All silages treated with additives, except for the silage treated with sodium benzoate, had lower ethanol content than the control silage $(\mathrm{P}<0.05)$ but, since alcoholic fermentation was not eliminated, gas losses and total DML were still high (above $15 \%$ and $19 \%$ of DM, respectively) during ensilage (Figure 1). The characteristic loss of substratum (sugars) due to alcoholic fermentation caused fiber components, ash, $\mathrm{Ca}$ and $\mathrm{P}$ to become more concentrated in these silages, relative to the fresh sugarcane. Partial control of alcoholic fermentation was sufficient to 
make silages treated with additives higher in TDN compared with control (Table 1).

Silages treated with urea exclusively (UR) and urea + benzoate $(\mathrm{UR}+\mathrm{SB})$ had similar contents of lactic, propionic and butyric acids but, acetic acid concentration and $\mathrm{pH}$ were higher in UR silage (Table 1). During ensilage, plant cell urease converts urea into ammonia. The alkaline property of ammonia causes delay in $\mathrm{pH}$ drop, favoring acetic acid production and higher DM losses (Kung \& Shaver, 2001). Accordingly, the higher dose of urea when the additive was applied alone resulted in higher acetic acid content, $\mathrm{pH}$ above recommended (4.5) and higher $(\mathrm{P}<0.05)$ gaseous losses $(17.2 \%$ vs. $16.2 \%$ of DM) compared with UR + SB silage (Figure 1). Ethanol content was similar $(\mathrm{P}>0.05)$ in both silages (average of $184 \mathrm{~g} / \mathrm{kg} \mathrm{DM}$ ), representing approximately an $18 \%$ reduction in alcohol concentration relative to control (Figure 1). Total DML did not differ $(\mathrm{P}>0.05)$ between UR and UR + SB silages (average of $20.7 \%$ of DM), representing a $31 \%$ reduction in DML compared with control. The higher amount of nitrogen added to the forage in UR resulted in higher $\mathrm{CP}$ content compared with $\mathrm{UR}+\mathrm{SB}$ silage (Table 1). Lignin and ash contents were lower and TDN was approximately $7 \%$ higher for the UR + SB silage compared with the silage treated with urea alone.

The reduction in alcohol production observed in UR and UR + SB silages may be credited to the toxic effect of ammonia on yeasts (Alli et al., 1983). Despite indication that conversion of urea into ammonia may be low in sugarcane silages (Nussio et al., 2006), Castro Neto et al. (2008) reported $33 \% \mathrm{~N}-\mathrm{NH}_{3}$ (relative to total $\mathrm{N}$ ) in DM and reduced ethanol yield in sugarcane silage treated with urea $(5 \mathrm{~g} / \mathrm{kg}$ FF). Some results in this experiment agree with Pedroso et al. (2007), who also observed reduced total DML and higher nutritional value for silages treated with urea exclusively, in doses ranging from 5 to $15 \mathrm{~g} / \mathrm{kg} \mathrm{FF}$, compared with untreated silage. Pedroso et al. (2008) reported reduction in yeasts, lower ethanol content and higher digestibility for silage treated with urea $(5 \mathrm{~g} / \mathrm{kg} \mathrm{FF})$, despite an elevation in $\mathrm{pH}$, but these authors considered that intensification of effluent production enhanced total DML in the silage, compared with the silage produced without additive. Siqueira et al. (2010) obtained elevation in $\mathrm{N}-\mathrm{NH}_{3}$, from $2.9 \%$ to $14.7 \%$ of total $\mathrm{N}, \mathrm{pH}$ in the upper limit (4.2) and high gaseous losses in silage treated with urea $(15 \mathrm{~g} / \mathrm{kg} \mathrm{FF})$, without alteration in silage buffering capacity.

Results for sodium benzoate applied exclusively (SB) were inferior compared with results for the additive combined with urea. Neutral detergent fiber and ADF contents were similar in both silages but lignin and ash were more

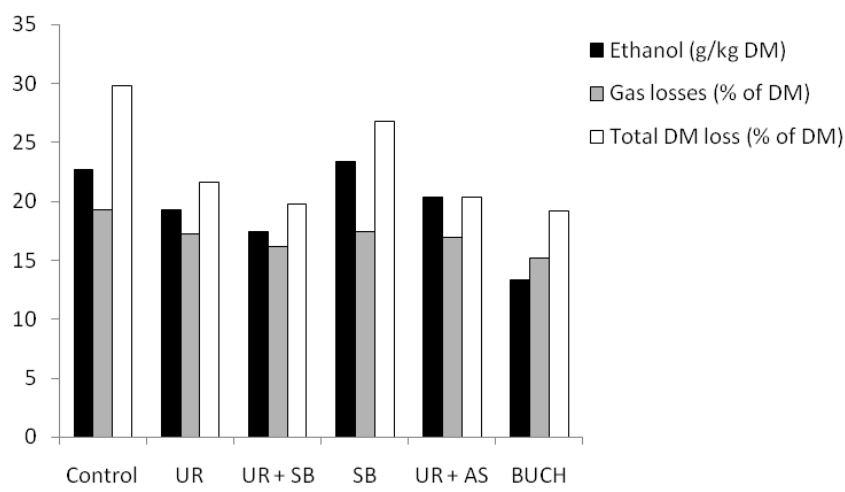

Control $=$ silage without additive; $\mathrm{UR}=$ silage with urea $(10 \mathrm{~g} / \mathrm{kg}$ of fresh forage - FF); UR + SB = silage with urea $(5 \mathrm{~g} / \mathrm{kg} F F)+$ sodium benzoate $(0.5 \mathrm{~g} / \mathrm{kg} \mathrm{FF}) ; \mathrm{SB}=$ sodium benzoate $(1 \mathrm{~g} / \mathrm{kg} \mathrm{FF}) ; \mathrm{UR}+\mathrm{AS}=$ urea + ammonium sulfate in a 9:1 relation $(10 \mathrm{~g} / \mathrm{kg} \mathrm{FF}) ; \mathrm{BUCH}=$ Lactobacillus buchneri $\left(5 \times 10^{4} \mathrm{cfu} / \mathrm{g} \mathrm{FF}\right)$

Figure 1 - Ethanol concentration and dry matter losses in sugarcane silages treated with chemical additives or a bacterial inoculant.

Table 1 - Chemical composition of fresh sugarcane and experimental silages ${ }^{1}$ ( $\mathrm{g} / \mathrm{kg} \mathrm{DM}$, unless otherwise stated)

\begin{tabular}{|c|c|c|c|c|c|c|c|c|}
\hline Element & Sugarcane & Control & UR & $\mathrm{UR}+\mathrm{SB}$ & $\mathrm{SB}$ & $\mathrm{UR}+\mathrm{AS}$ & $\mathrm{BUCH}$ & SE \\
\hline $\mathrm{DM}(\mathrm{g} / \mathrm{kg} \mathrm{FF})$ & $272 \mathrm{a}$ & $202 c$ & $224 b$ & $228 b$ & $209 c$ & $227 b$ & $229 b$ & 7 \\
\hline Crude protein & $25.6 \mathrm{~d}$ & $42.0 \mathrm{c}$ & $151 \mathrm{a}$ & $72.3 b$ & $40.8 \mathrm{c}$ & $144 \mathrm{a}$ & $36.0 \mathrm{c}$ & 5 \\
\hline NDF & $387 \mathrm{~d}$ & $637 \mathrm{ab}$ & $603 c$ & $645 \mathrm{a}$ & $656 a$ & $582 \mathrm{c}$ & $612 b c$ & 20 \\
\hline $\mathrm{ADF}$ & $240 \mathrm{~d}$ & $442 \mathrm{a}$ & $411 \mathrm{~b}$ & $382 b c$ & $398 b c$ & $390 \mathrm{bc}$ & $376 \mathrm{c}$ & 20 \\
\hline Lignin & $37.6 \mathrm{~d}$ & $86.9 \mathrm{a}$ & $86.9 \mathrm{a}$ & $49.6 c$ & $62.9 \mathrm{~b}$ & $45.0 \mathrm{~cd}$ & $43.4 \mathrm{~cd}$ & 7 \\
\hline Ash & $31.2 \mathrm{c}$ & $47.1 \mathrm{a}$ & $45.0 \mathrm{a}$ & $42.4 b$ & $45.2 \mathrm{a}$ & $44.9 \mathrm{a}$ & $40.7 b$ & 1.6 \\
\hline $\mathrm{Ca}$ & $16.2 \mathrm{~d}$ & $26.6 \mathrm{a}$ & $25.5 \mathrm{ab}$ & $25.1 \mathrm{~b}$ & $24.9 b$ & $24.4 b$ & $21.8 \mathrm{c}$ & 0.8 \\
\hline $\mathrm{P}$ & $4.30 \mathrm{~d}$ & $6.70 \mathrm{a}$ & $5.82 \mathrm{bc}$ & $5.67 \mathrm{c}$ & $6.50 \mathrm{ab}$ & $5.77 \mathrm{c}$ & $6.10 \mathrm{~b}$ & 0.5 \\
\hline TDN & $693 a$ & $538 \mathrm{e}$ & $568 \mathrm{~d}$ & $605 c$ & $571 \mathrm{~d}$ & $637 b$ & $628 \mathrm{~b}$ & 13 \\
\hline $\mathrm{pH}$ & nd & $4,2 \mathrm{a}$ & $4,5 \mathrm{a}$ & $3,7 b$ & $3,5 b$ & $4,2 \mathrm{a}$ & $3,4 \mathrm{~b}$ & 0,26 \\
\hline Lactic acid & nd & $52.0 \mathrm{c}$ & $79.4 \mathrm{a}$ & $76.2 \mathrm{ab}$ & $70.1 \mathrm{~b}$ & $75.8 \mathrm{ab}$ & $50.8 \mathrm{c}$ & 4.8 \\
\hline Acetic acid & nd & $10.1 \mathrm{c}$ & $21.4 \mathrm{~b}$ & $12.1 \mathrm{c}$ & $11.0 \mathrm{c}$ & $12.7 \mathrm{c}$ & $32.9^{\mathrm{a}}$ & 3.0 \\
\hline Propionic acid & nd & $0.09 \mathrm{~b}$ & $0.13 \mathrm{a}$ & $0.11 \mathrm{ab}$ & $0.12 \mathrm{ab}$ & $0.12 \mathrm{ab}$ & $0.05 \mathrm{c}$ & 0.03 \\
\hline Butyric acid & nd & $0.99 \mathrm{bc}$ & $1.08 \mathrm{ab}$ & $1.03 \mathrm{bc}$ & $1.23 \mathrm{a}$ & $1.02 \mathrm{bc}$ & $0.92 \mathrm{c}$ & 0.11 \\
\hline
\end{tabular}

${ }^{1}$ Control = silage without additive; UR = silage with urea $(10 \mathrm{~g} / \mathrm{kg} \mathrm{FF}) ; \mathrm{UR}+\mathrm{SB}=$ urea $(5 \mathrm{~g} / \mathrm{kg} \mathrm{FF})+$ sodium benzoate $(0.5 \mathrm{~g} / \mathrm{kg}$ FF $) ; \mathrm{SB}=\mathrm{sodium}$ benzoate $(1 \mathrm{~g} / \mathrm{kg}$ FF $)$

$\mathrm{UR}+\mathrm{AS}=$ urea + ammonium sulfate in a $9: 1$ relation $(10 \mathrm{~g} / \mathrm{kg} \mathrm{FF}) ; \mathrm{BUCH}=$ Lactobacillus buchneri $\left(5 \times 10^{4} \mathrm{cfu} / \mathrm{g} \mathrm{FF}\right)$.

$\mathrm{a}, \mathrm{b}, \mathrm{c}, \mathrm{d}$ Means within a row with different superscripts differ $(\mathrm{P}<0.05)$ by $t$ test.

$\mathrm{FF}=$ fresh forage; $\mathrm{DM}=$ dry matter; $\mathrm{NDF}=$ neutral detergent fiber; $\mathrm{ADF}=$ acid detergent fiber; $\mathrm{nd}=$ not determined. 
concentrated in SB resulting in lower TDN, compared with $\mathrm{UR}+\mathrm{SB}$ (Table 1). Appling benzoate in a dose $100 \%$ greater than the dose used in the mixture of additives did not reduce ethanol content in the silage $(\mathrm{P}>0.05)$ and, despite the reduction in gaseous losses $(\mathrm{P}<0.05)$, total DML $(26.8 \%$ of $\mathrm{DM})$ was not different $(\mathrm{P}>0.05)$ from control (Figure 1). Alcoholic fermentation was not inhibited despite the higher lactic acid content and lower $\mathrm{pH}$ in the silage treated with benzoate compared with control (Table 1), confirming the inefficacy of low $\mathrm{pH}$ and lactic acid in controlling yeasts (McDonald et al., 1991; Moon, 1983).

Sodium benzoate is a common food preservative, which has long been known as an effective inhibitor of yeast and molds (Woolford, 1975). At low pH, sodium benzoate converts into undissociated benzoic acid and, in this form, is able to cross the yeast cell membrane. The exact mechanism by which cell growth is inhibited is yet to be defined. It appears to involve cytosol acidification by acid dissociation on the higher $\mathrm{pH}$ inside the cell, disruption of membrane homeostasis and mitochondrial physiology, among others (Krebs et al., 1983; Hazan et al., 2004). In this trial, applying benzoate did not reduce alcoholic fermentation but somehow improved the nutritional value of the silage, which presented lower FDA and lignin contents and higher TDN compared with the untreated silage (Table 1).

Pedroso et al. (2007) reported unsatisfactory results when benzoate was applied solely $(1 \mathrm{~g} / \mathrm{kg} \mathrm{FF})$ at the ensiling of sugarcane, but in a subsequent evaluation, application of the additive reduced alcohol yield and losses, improving silage digestibility and aerobic stability (Pedroso et al., 2008). Siqueira et al. (2007) and Siqueira et al. (2010) observed improved DM recovery and aerobic stability in silages treated with this additive, but ethanol was not analyzed. It is possible to speculate that higher doses of benzoate could be more effective, but the consequent increase in production costs would probably make it impractical.

Results discussed until this point indicate the occurrence of a synergistic effect between additives when urea and sodium benzoate were applied simultaneously. Most of the quality parameters were improved in UR + SB silage compared with silages treated with urea or sodium benzoate alone. If this combination of additives proves to be efficient in future evaluations, its use may bring some other benefits to farmers besides the control of alcoholic fermentation in the silages: the low dose of urea allows partial correction of protein content in the silage without the negative aspects that may occur when urea is applied in higher doses, such as inadequate $\mathrm{pH}$ and higher DM losses in the silage; applying urea at ensiling poses less risk of intoxication to animals than mixing the product with the forage in the feed bunk, the traditional way to correct CP content in sugarcane (Alvarez \& Preston, 1976).

Applying urea + ammonium sulfate (UR + AS) had the same effect $(\mathrm{P}>0.05)$ on ethanol content, gas losses and total DML in the silage as urea applied exclusively (Figure 1). Crude protein, NDF, ADF and mineral contents were similar in both silages but UR + AS silage had less lignin and acetic acid contents and higher TDN than the UR silage (Table 1). Although there was no difference in final $\mathrm{pH}$ among these silages, the slightly higher dose of urea in UR compared with UR + AS (10 vs. $9 \mathrm{~g} / \mathrm{kg} \mathrm{FF}$ ) seems to have been sufficient to delay $\mathrm{pH}$ drop, allowing enterobacteria growth for a longer period, which could explain the higher acetic acid content in the silage. On the other hand, the more adequate fermentation pattern in $\mathrm{Ur}+\mathrm{AS}$ silage, resulted in less acetic acid in the silage, somehow reducing lignin content and, consequently, elevating silage TDN compared with UR. Results indicate that applying urea + ammonium sulfate to sugarcane at ensiling improves fermentation and might be a practical way to obtain a more appropriate $\mathrm{S}: \mathrm{N}$ balance in diets containing these silages. The indication that applying the mixture results in silage with higher TDN than urea applied alone must be confirmed in further trials.

Inoculation with $L$. buchneri caused significant increase in acetic acid concentration in the silage, but contents of lactic and butyric acids and $\mathrm{pH}$ did not differ from control (Table 1). The inoculated silage had the lowest ethanol content among all silages (130 g/ $\mathrm{kg}$ in $\mathrm{DM})$, corresponding to a $41 \%$ reduction $(\mathrm{P}<0.05)$ in alcohol concentration relative to the untreated silage (Figure 1). The higher efficiency of inoculation in controlling alcoholic fermentation resulted in the lowest $(\mathrm{P}<0.05)$ gaseous losses among silages $(15.2 \%$ of $\mathrm{DM})$, representing a $22 \%$ reduction compared with the silage without additive. Total DML was approximately $36 \%$ lower $(\mathrm{P}<0.05)$ in the inoculated silage compared with control $(19.2 \times 29.8 \%$ of DM $)$. The inoculated silage presented NDF, ADF, lignin and ash concentrations in the lower and TDN in the highest level observed among silages (Table 1).

The heterolactic bacteria Lactobacillus buchneri ferment lactic acid to acetic acid and small amounts of 1.2 propanediol, propionic acid and carbon dioxide (Oude Eelferink et al., 2001). Acetic acid has high fungicidal effect (Woolford, 1975) and inoculation with L. buchneri has consistently increased its concentration in grass and corn silages, reducing yeast counts (Driehuis et al., 1999; Kleinschmit et al., 2005; Pedroso et al., 2010). Considering sugarcane ensilage, inoculation with these bacteria also enhanced acetic acid production in evaluations by Mendes et al. (2008) and Pedroso et al. (2007) and reduced 
ethanol content and losses in trials by Pedroso et al. (2007), Pedroso et al. (2008) and Siqueira et al. (2010). Inoculation with $L$. buchneri had no effect on ethanol production in research by Freitas et al. (2006).

\section{Conclusions}

Inoculation with L. buchneri is effective in reducing ethanol content and losses in sugarcane silages. Urea and sodium benzoate are more efficient when applied together, indicating the occurrence of synergistic effect between these additives. Applying urea mixed with ammonium sulfate has the same overall effect as urea alone and may facilitate feed management in the farm. The natural variability in results from experiments involving silage fermentation indicates that further evaluations are necessary to broaden the database of additives for the ensilage of sugarcane.

\section{Acknowledgements}

The authors gratefully acknowledge Lallemand Animal Nutrition for supplying the bacterial inoculant.

\section{References}

ALLI, I.; FAIRBAIRN, R.; BAKER, B.E. The effects of ammonia on the fermentation of chopped sugarcane. Animal Feed Science and Technology, v.9, p.291-299, 1983.

ALVAREZ, J.; PRESTON T.R. Studies on urea utilization in sugar cane diets: effect of level. Tropical Animal Production, v.3, p.47-54, 1976

ASSOCIATION OF OFFICIAL ANALYTICAL CHEMISTIS AOAC. Official methods of analysis. 15.ed. Arlington, 1990. v. $1,1117 \mathrm{p}$.

CASTRO NETO, A.G.; MOLINA, L.R.; GONÇALVES, L.C. et al. Parâmetros de fermentação de silagens de cana-de-açúcar submetidas a diferentes tratamentos. Arquivo Brasileiro de Medicina Veterinária e Zootecnia, v.60, n.5, p.1150-1156, 2008.

DRIEHUIS, F.; WIKSELAAR, P.G. The occurrence and prevention of ethanol fermentation in high-dry-matter grass silage. Journal of Science of Food and Agriculture, v.80, p.711-718, 2000.

FERREIRO, H.M.; SUTHERLAND, T.M.; WILSON, A. Effect of nitrogen source on rumen fermentation in diets based on sugar cane. Tropical Animal Production, v.2, p.319-322, 1977.

FREITAS, A.W.P.; PEREIRA, J.C.; ROCHA, F.C. et al. Avaliação da qualidade nutricional da silagem de cana-de-açúcar com aditivos microbianos e enriquecida com resíduo da colheita de soja. Revista Brasileira de Zootecnia, v.35, p.38-47, 2006.

HAZAN, R.; LEVINE, A.; ABELIOVICH, H. Benzoic acid, a weak organic acid food preservative, exerts specific effects on intracellular membrane trafficking pathways in Saccharomyces cerevisiae. Applied and Environmental Microbiology, v.70, p.4449-4457, 2004.

KLEINSCHMIT, D.H.; SCHMIDT, R.J.; KUNG JUNIOR, L. The effects of various antifungal additives on the fermentation and aerobic stability of corn silage. Journal of Dairy Science, v. 88, p.2130-2139, 2005.

KREBS, H.A.; WIGGINS, D.; STUBBS, M. Studies on the mechanism of the antifungal action of benzoate. Biochemical Journal, v.214, p.657-663, 1983.
KUNG, L.; SHAVER, R. Interpretation and use of silage fermentation analysis reports. Focus on Forage, v.3, n.13, p.1-5, 2001

McDONALD, P.; HENDERSON, A.R.; HERON, S.J.E. The biochemistry of silage. 2.ed. Marlow: Chalcomb Publication, 1991. 340p

MENDES, C.Q.; SUSIN, I.; PIRES, A.V. et al. Desempenho, parâmetros da carcaça e comportamento ingestivo de cordeiros alimentados com cana-de-açúcar ensilada ou in natura. Arquivo Brasileiro de Medicina Veterinária e Zootecnia, v. 60 , p.733-740, 2008.

MOON, N.J. Inhibition of the growth of acid tolerant yeasts by acetate, lactate and propionate and their synergistic mixtures. Journal of Applied Bacteriology, v.55, p.453-460, 1983.

NUSSIO, L.G.; SCHMIDT, P.; SCHOGOR, A.L.; MARI, L.J. Canade-açúcar como alimento para bovinos. In: SIMPÓSIO SOBRE MANEJO ESTRATÉGICO DA PASTAGEM, 3., 2006, Viçosa, MG. Anais... Viçosa, MG: UFV, 2006. p.277-328.

OUDE EELFERINK, S.J.H.W.; KROONEMAN, J.; GOTTSCHAL, J.C. et al. Anaerobic conversion of lactic acid to acetic acid and 1,2-propanediol by Lactobacillus buchneri. Applied and Environmental Microbiology, v.67, p.125-132, 2001.

PEDROSO, A.F.; NUSSIO, LG.; PAZIANI, S.F. et al. Fermentation and epiphytic microflora dynamics in sugar cane silage. Scientia Agricola, v.62, p.427-432, 2005.

PEDROSO, A.F.; NUSSIO, L.G.; LOURES, D.R.S. et al. Efeito do tratamento com aditivos químicos e inoculantes bacterianos nas perdas e na qualidade de silagens de cana-de-açúcar. Revista Brasileira de Zootecnia, v.36, p.558-564, 2007.

PEDROSO, A.F.; NUSSIO, L.G.; LOURES, D.R.S. et al. Fermentation, losses, and aerobic stability of sugarcane silages treated with chemical and bacterial additives. Scientia Agricola, v.65, p.567-691, 2008.

PEDROSO, A.F.; ADESOGAN, A.T.; QUEIROZ, O.C.M. Control of Escherichia coli $0157: \mathrm{H} 7$ in corn silage with or without various inoculants: efficacy and mode of action. Journal of Dairy Science, v.93, p.1098-1104, 2010.

SCHMIDT, P. Aditivos químicos e biológicos no tratamento da cana-de-açúcar para alimentação de bovinos. In: JOBIM, C.C.; CECATO, U.; CANTO, M.W. et al. (Eds.) Produção e utilização de forragens conservadas. Maringá: UEM, 2008. p.117-152.

SIGMA-ALDRICH Co. Analyzing fatty acids by packed column gas chromatography. Bellefonte: SUPELCO - Bulletin 856B. 1998. 12p.

SIQUEIRA, G.R.; REIS, R.A.; SCHOCKEN-ITURRINO, R.P. et al. Perdas de silagens de cana-de-açúcar tratadas com aditivos químicos e bacterianos. Revista Brasileira de Zootecnia, v.36, n.6, p.2000-2009, 2007.

SIQUEIRA, G.R.; REIS, R.A.; SCHOCKEN-ITURRINO, R.P. et al. Queima e aditivos químicos e bacterianos na ensilagem de canade-açúcar. Revista Brasileira de Zootecnia, v.39, p.103-112, 2010 .

STATISTICAL ANALYSES SYSTEM - SAS. System for Microsof Windows. Release 9.1. Cary: SAS Institute, 2003. (CD-ROM).

Van SOEST, P.J.; ROBERTSON, J.B. Analysis of forages and fibrous foods. Ithaca: Cornell University, 1985. 202p.

WEISS, W.P.; CONRAD, H.R.; ST. PIERRE, N.R. A theoreticallybased model for predicting total digestible nutrient values of forages and concentrates. Animal Feed Science and Technology, v.39, p.95-110, 1992.

WILSON, R.K.A. A rapid accurate method for measuring volatile fatty acids and lactic acid in silage. Research Report. Dublin, Ireland: Agricultural Institute, Dunsinea Research Centre, 1971. 7p.

WOOLFORD, M.K. Microbial screening of food preservatives, cold sterilants, and specific antimicrobial agents as potential silage additives. Journal of the Science of Food and Agriculture, v.26, p.229-237, 1975. 